\title{
Influence of the compression pressure ratio on the energetic and exergetic efficiency of a solar driven regenerative closed Brayton cycle with helium as working fluid
}

\author{
S. Sanchez-Orgaz ${ }^{1}$, J. Rodríguez Martín ${ }^{1}$, A. Jiménez Álvaro ${ }^{1}$, I. López Paniagua ${ }^{1}$, C. González
} Fernández ${ }^{1}$ and R. Nieto Carlier ${ }^{1}$

${ }^{1}$ ETSI Industriales-Universidad Politécnica de Madrid, Spain

Calle José Gutiérrez Abascal, 28006 Madrid (Spain)

Phone/Fax number: +0034 913363150, e-mail: susana.sanchez.orgaz@upm.es; orcid.org/0000-0002-5215-930X

\begin{abstract}
One of the causes of the lack of competitiveness of solar thermal energy is its low energy and exergetic performance Therefore, it is necessary to investigate the possibility of using more efficient cycles. Closed Brayton cycles are an attractive alternative because of their good performance achieved in other applications on the same range of temperatures.

In this work the energy and exergy efficiency of a closed Brayton regenerative cycle have been calculated. The working fluid of the power block is helium. Also, the influence of the compressor pressure ratio on the energetic and exergetic efficiency has been analyzed. For this, a model of the plant in Engineering Equation Solver (EES) has been made. The maximum energy efficiency is $22.44 \%$ while the maximum exergetic efficiency is $24.09 \%$. Both are obtained for a compressor pressure ratio of 1.634 .
\end{abstract}

\section{Key words}

Helium, Closed Brayton, solar thermal, energetic, exergetic

\section{Introduction}

Solar thermal plants usually operates on subcritical steam Rankine cycles of low temperature. The efficiency of these cycles is low. The study of alternative thermodynamic cycles with higher efficiency, it is fundamental to development of solar thermal energy [1].

This work evaluates the energetic and exergetic efficiency of a solar driven regenerative closed Brayton cycle with helium as working fluid. Also the influence of the compression ratio is analyzed. The closed Brayton cycles have already been used with other energy sources such as nuclear energy [1]. Helium has some advantages compared to others working fluids: higher thermal conductivity, higher thermal capacity and it is an inert gas [2].

\section{System description}

Figure 1 shows a simple scheme of the power plant. It is a regenerative closed Brayton cycle with two compression stages, an intercooler, a recuperator, an expansion stage and a precooler. The working fluid is helium. This configuration has been recommended in references [2] and [3]. The solar technology is a solar tower with air as heat transfer fluid. The out temperature of the air is $1000{ }^{\circ} \mathrm{C}$. It is adequate for the turbine inlet temperature $\left(950^{\circ} \mathrm{C}\right)$. The main operational parameters of the cycle are included on table I. The same value of pressure losses $\Delta P$ is assumed for all heat exchangers.

Table I. Main parameters of the cycle.

\begin{tabular}{|l|c|c|l|}
\hline Parameter & Symbol & Value & Reference \\
\hline $\begin{array}{l}\text { Turbine polytropic } \\
\text { efficiency }\end{array}$ & $\eta_{T}[\%]$ & 89 & {$[3]$} \\
\hline $\begin{array}{l}\text { Compresor polytropic } \\
\text { efficiency }\end{array}$ & $\eta_{C}[\%]$ & 86 & {$[3]$} \\
\hline Recuperator effectiveness & $\varepsilon[\%]$ & 90 & {$[3]$} \\
\hline Pressure losses & $\Delta P[\%]$ & 1 & {$[4]$} \\
\hline $\begin{array}{l}\text { LP Compressor inlet } \\
\text { pressure }\end{array}$ & $P_{1}[\mathrm{bar}]$ & 1.5 & {$[3]$} \\
\hline $\begin{array}{l}\text { LP Compressor inlet } \\
\text { temperature }\end{array}$ & $T_{1}[\mathrm{~K}]$ & 303.15 & {$[3]$} \\
\hline Heliostat field efficiency & $\eta_{\text {hel }}[\%]$ & 64.28 & {$[5]$} \\
\hline Receptor efficiency & $\eta_{r e c}[\%]$ & 75 & {$[5]$} \\
\hline
\end{tabular}




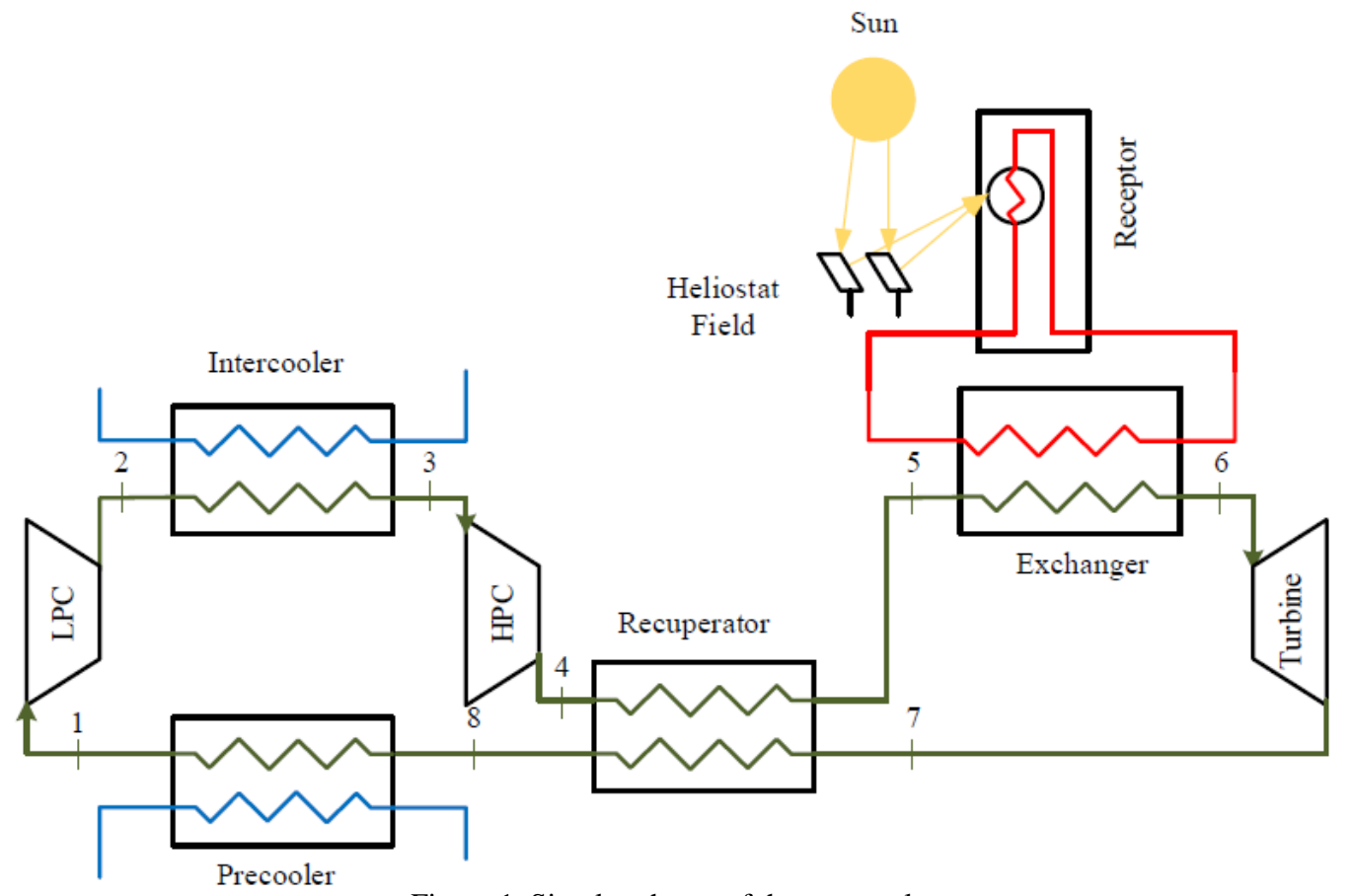

Figure 1. Simple scheme of the power plant

\section{Methodology}

The plant is evaluated from an energetic and an exergetic point of view. The following parameters are calculated:

- Compressor pressure ratio $\delta$ : It is calculated by the equation 1.

$$
\delta=\frac{P_{2}}{P_{1}}=\frac{P_{4}}{P_{3}}
$$

- $\quad$ Net power output $\dot{W}$ : It is defined as sum of the expansion power and compression power

$$
\dot{W}=\dot{W}_{T}+\dot{W}_{L P C}+\dot{W}_{H P C}
$$

- Solar power input $\dot{Q}_{S F}$ : It is calculated as the ratio between the thermal power input $\dot{Q}_{S}$ on the cycle and the product of heliostat field efficiency $\eta_{\text {hel }}$ and receptor efficiency $\eta_{\text {rec }}$.

$\dot{Q}_{S F}=\frac{\dot{Q}_{S}}{\eta_{\text {hel }} \cdot \eta_{\text {rec }}}=\frac{\dot{m}_{6} \cdot h_{6}-\dot{m}_{5} \cdot h_{5}}{\eta_{\text {hel }} \cdot \eta_{\text {rec }}} 10^{-3}$

- Energetic efficiency $\eta$ : It is the ratio between the net power output $\dot{W}$ and the solar power input $\dot{Q}_{S F}$.

$$
\eta=\frac{\dot{W}}{\dot{Q}_{S F}}
$$

- $\quad$ Exergetic efficiency $\psi$ : It is calculated by equation 5 .

$$
\psi=1-\frac{\dot{I}}{\dot{E}_{S F}}
$$

Where:

- $\dot{I}$ : Exergy destruction [MW]. It is the sum of the exergy destruction of each power plant components. They have been grouped in solar block, turbomachinery (compressors and turbine) and heat exchangers (precooler, intercooler and recuperator). The contribution of each group is calculated by equations 6,7 and 8

$$
\% \text { Solar Block }=\frac{\dot{I}_{S B}}{\dot{I}} 100
$$

$$
\begin{gathered}
\% \text { Heat exchangers }=\frac{\dot{I}_{\text {exch }}}{\dot{I}} 100 \\
\% \text { Turbomachinery }=\frac{\dot{I}_{\text {turbo }}}{\dot{I}} 100
\end{gathered}
$$

Where $\dot{I}_{S B}$ exergy destruction on solar block [MW], $\dot{I}_{\text {exch }}$ exergy destruction on heat exchangers [MW], $\dot{I}_{\text {turbo }}$ exergy destruction on turbomachinery [MW] and $\dot{I}$ exergy destruction [MW].

- $\dot{E}_{S F}$ : Solar exergy input [MW]: It is calculated by the equation 9 [6]. 


$$
\dot{E}_{S F}=\dot{Q}_{S F} \cdot\left(1-\frac{4}{3} \cdot\left(\frac{T_{0}}{T_{s}}\right)+\frac{1}{3} \cdot\left(\frac{T_{0}}{T_{s}}\right)^{4}\right)
$$

Where $\dot{Q}_{S F}$, is the solar power input, $T_{s}$ is the sun temperature and $T_{0}$ is the ambient temperature.

These parameters are calculated from the thermodynamic properties (enthalpy, entropy and exergy) of each stream of the cycle. Therefore, a thermodynamic model of the power plant have been implemented in Engineering Equation Solver (EES) [7]. The working fluid (helium) have been modelled as an ideal gas with constant heat capacity. The ambient temperature and pressure are 298.15 K and 1.01325 bar.

\section{Simulation and Results}

\section{A. Energetic analysis.}

Figure 2 represents influence of the compressor pressure ratio on the net power output. The maximum net power output is 23.39 MW with a compressor pressure ratio of de 2.519 .

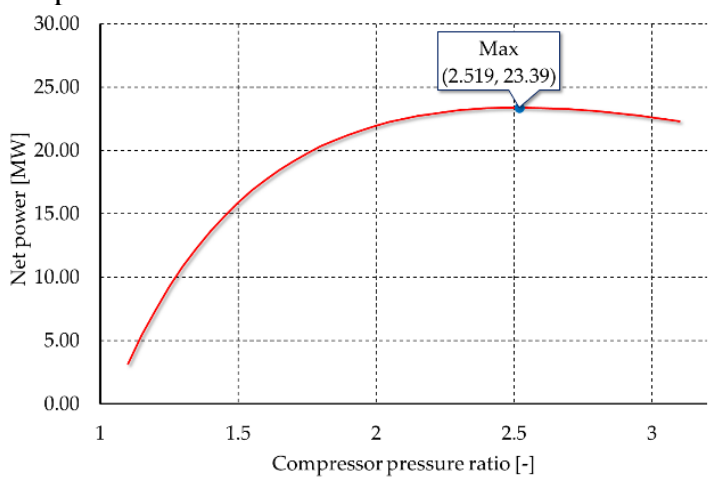

Fig. 2 Effect of the compression pressure ratio on the net power.

The trend of solar power input is show on figure 3. Solar power input sharply rises when the compressor ratio is increased.

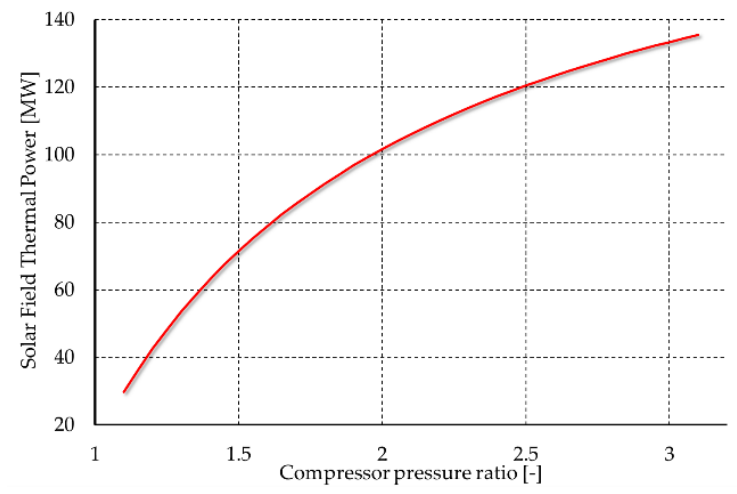

Fig. 3 Effect of the compression pressure ratio on the solar field thermal power.

According to the figure 4, the energetic efficiency achieves maximum of $22.44 \%$ at compressor pressure ratio of 1.634 .

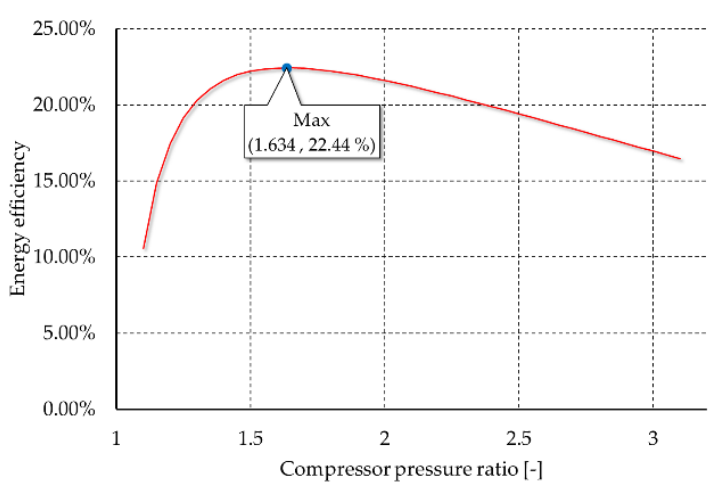

Fig. 4 Effect of the compressor pressure ratio on the cycle efficiency.

Table II summarizes the energetic parameters at maximum net power design $(\delta=2.519)$ and maximum energetic efficiency design $(\delta=1.634)$. At maximum energetic efficiency design, the net power output is a $28.30 \%$ lower than the maximum net power out . But the solar power input is quite inferior (48.99\%) to the value on maximum net power output design. The maximum energetic efficiency is recommended owing to the elevated costs of the solar technology.

Table II. Comparison of the maximum power and maximum efficiency designs.

\begin{tabular}{|l|c|c|c|}
\hline & $\begin{array}{c}\text { Maximum } \\
\text { power } \\
\delta=2.519\end{array}$ & $\begin{array}{c}\text { Maximum } \\
\text { energetic } \\
\text { efficiency } \\
\delta=1.634\end{array}$ & $\begin{array}{c}\text { Deviation } \\
{[\%]}\end{array}$ \\
\hline Net Power [MW] & 23.39 & 18.23 & 28.30 \\
\hline $\begin{array}{l}\text { Solar field thermal } \\
\text { power [MW] }\end{array}$ & 121.06 & 81.26 & 48.99 \\
\hline Net efficiency [\%] & 19.32 & 22.44 & 3.836 \\
\hline
\end{tabular}

\section{B. Exergetic analysis.}

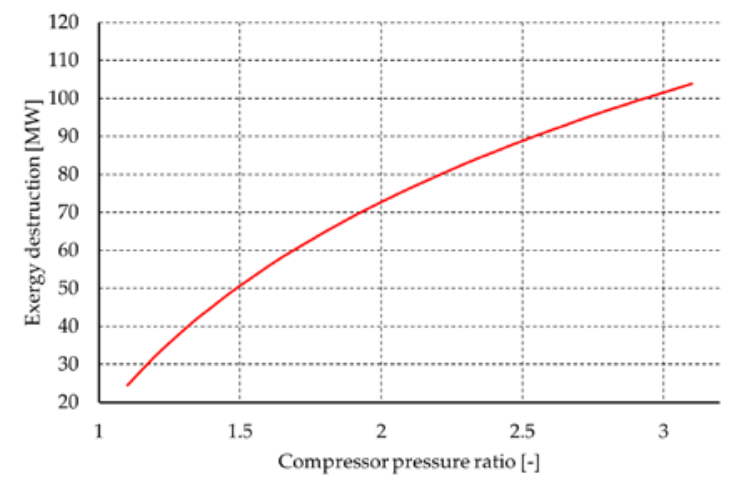

Fig. 5 Effect of the compression ratio on exergy destruction.

Figure 5 represents the variation of the exergy destruction as function of the compressor pressure ratio. The exergy destruction rise with compressor ratio. However, the influence of each device on the total exergy destruction is different.

The exergy destruction percentage on the solar block (equation 6) achieves a maximum (85 \%) on a compressor pressure ratio of 1.846 (figure 6). The exergy destruction 
percentage on the heat exchangers (equation 7) reaches a minimum of $8.728 \%$ on a compressor pressure ratio of 2.021 (figure 7). The percentage of exergy destruction on turbomachinery (equation 8) rises when compressor pressure ratio is increased (figure 8).

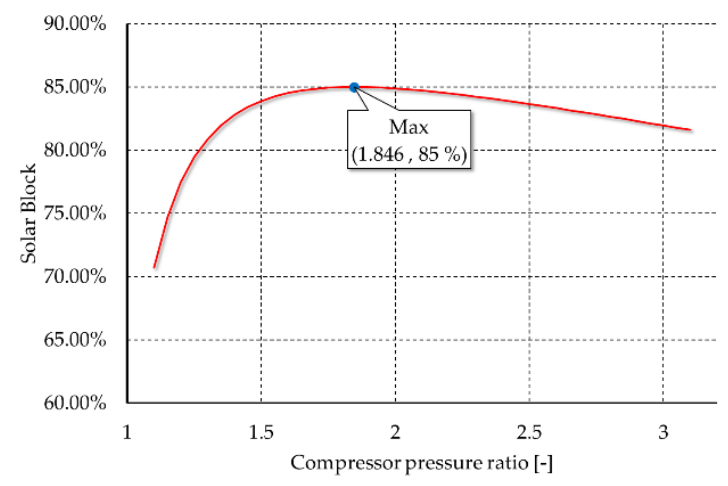

Fig.6. Effect of pressure compression pressure ratio on the percentage of solar block exergy destruction.

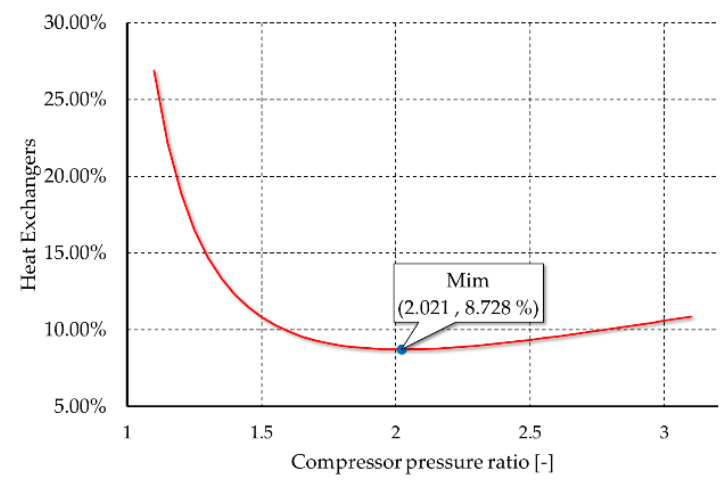

Fig. 7 Effect of pressure compression pressure ratio on the percentage of heat exchangers exergy destruction.

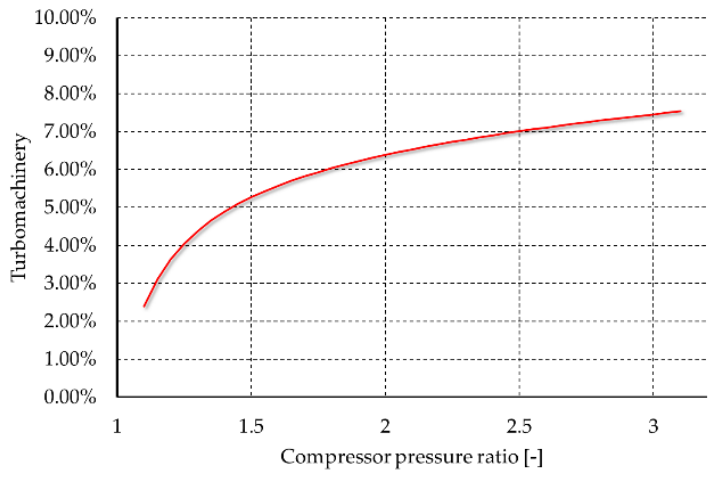

Fig. 8 Effect of compressor pressure ratio on the percentage of turbomachinery exergy destruction.

The influence of the compressor pressure ratio on the exergy efficiency is show non figure 5 . The maximum exergetic efficiency (24.09\%) coincides with the compressor ratio on maximum efficiency design $(\delta=1.634)$.

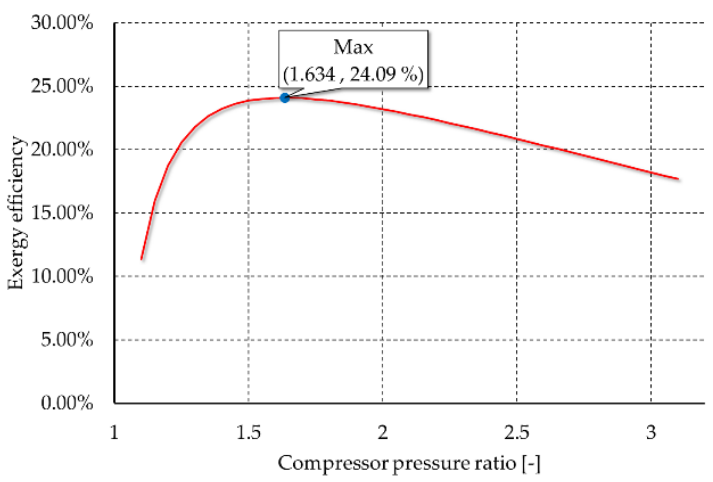

Fig. 9 Effect of the compressor pressure ratio on the exergy efficiency.

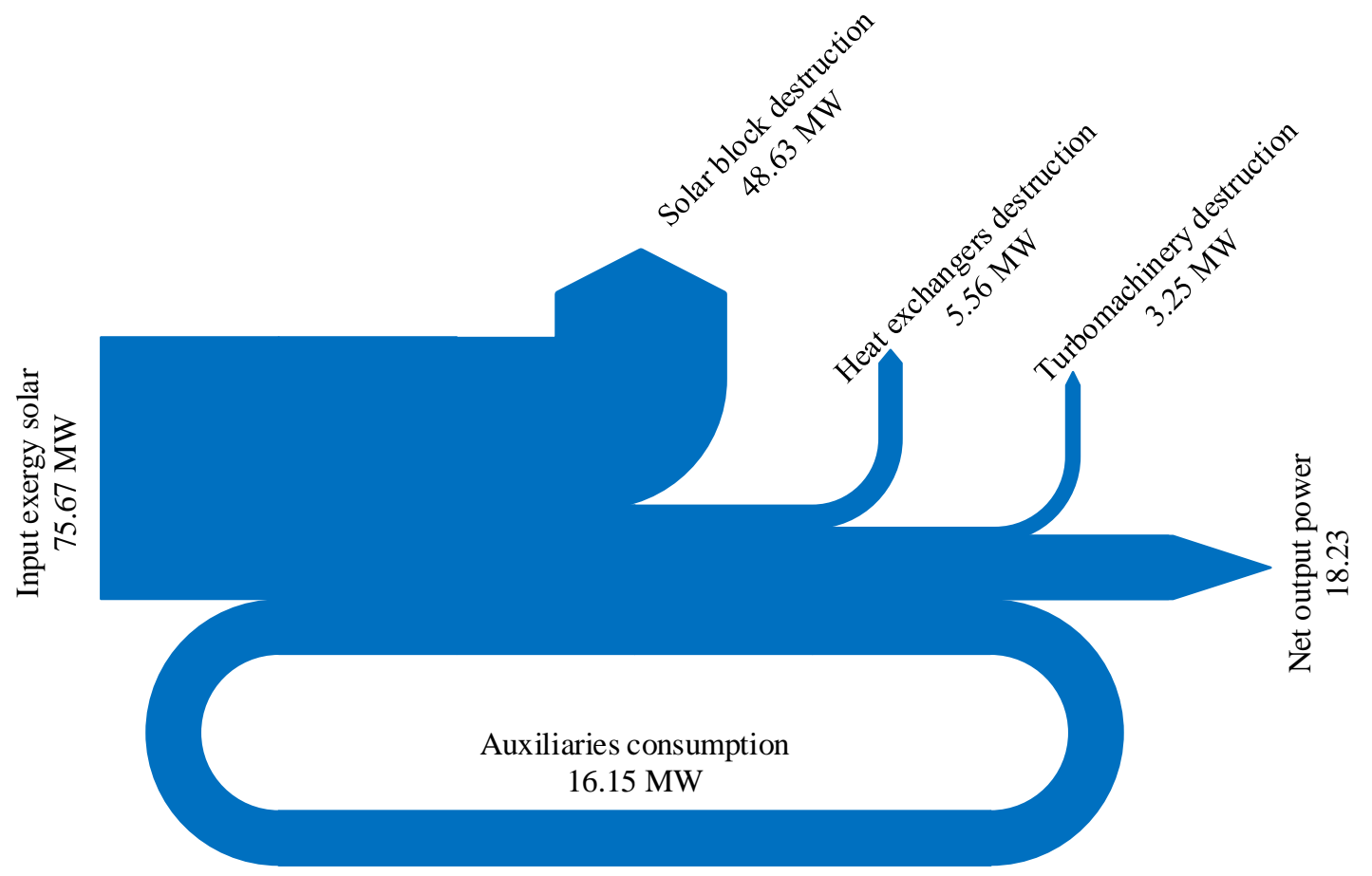

Fig. 10. Grassman diagram 
Figure 10 shows the Grassmann diagram on a maximum exergetic efficiency ( $\delta=1.634)$. The exergetic efficiency is $24.09 \%$. Solar block, heat exchangers and turbomachinery destruction are $64.2 \%, 7.35 \%$ and 4.29 $\%$ of the solar exergy input (75.67 MW).

\section{Conclusions}

The solar driven regenerative closed Brayton cycle with helium as working fluid could be an attractive alternative for the solar thermal energy. The energetic efficiency of this power plant $22.4 \%$ is higher than the efficiency of other power plant with solar tower as solar technology (Table II).

Table II. Energetic efficiency of some solar tower plants [8].

\begin{tabular}{|l|c|}
\hline Power Plant & $\begin{array}{c}\text { Energetic } \\
\text { Efficiency }\end{array}$ \\
\hline Solar Two & $13 \%$ \\
\hline Solar Tres & $19 \%$ \\
\hline Solar cuatro & $22 \%$ \\
\hline Solar 100 & $22 \%$ \\
\hline PS10 & $17 \%$ \\
\hline
\end{tabular}

When a closed regenerative Brayton is designed, it is important to select adequately the compressor pressure ratio. The compressor pressure ratio that maximizes the energetic and exergetic efficiencies $(\delta=1.634)$ is different from the value that maximizes the net power output $(\delta=2.519)$. From the investment costs point of view, it is better to design the power plant with the compressor pressure ratio that maximizes the energetic and exergetic efficiencies because the maximum power option requires a larger solar field (48.99\%) However, if the revenues are taken account, the maximum power design could be interesting because the increment of the net power output is significant (28\%). In general, when the power plant is built, the compressor pressure ratio will be between 1.634 and 2.519, seeking a balance between technical and economic costs.

\section{References}

[1] W.H Stein and R. Buck. Advanced power cycles for concentrated solar power. Solar Energy (2017), Vol. 152, pp. 91105.

[2] V. Zare and M. Hasanzadeh. Energy and exergy analysis of a closed Brayton cycle-based combined. Energy Conversion and Management (2016). Vol. 128, pp. 227-237.

[3] K. Kusterer, R. Braun, N. Moritz, G. Lin, and D. Bohn. Helium Brayton Cycles with Solar Central Receivers: Thermodaynamic and Design. ASME Turbo Expo 2012.

[4] K. Kusterer, R. Braun, N. Moritz, T. Sugimoto, K. Tanimura and D. Bohn. Comparative study of solar thermal Brayton cycles operated with helium or argon. ASME Turbo Expo 2013.

[5] S.M, Besarati and D.Y. Goswami. A computationally efficient method for the design of the heliostat field for solar power tower plant. Renewable Energy (2014). Vol. 69, pp. 226232.

[7] S.A. Kalogirou, S. Karellas, V. Badescu, and Braimakis. Exergy analysis on solar thermal systems: a better understanding of their sustainability. Renewable Energy (2016). Vol. 85, pp. 1328-1333.
[7] S.A Klein, S. A. and F.L Alvarado. Engineering equation solver. F-Chart Software. (2002).

[8] V. S. Reddy, S.C. Kaushik, K.R. Ranjan and S.K. Tyagi, State-of-the-art of solar thermal power plants- A review. Renewable and Sustainable Energy Reviews (2013). Vol. 27, 2013, pp. 258-273. 